\title{
Quantification of dynamic soil-vegetation feedbacks following an isotopically labelled precipitation pulse
}

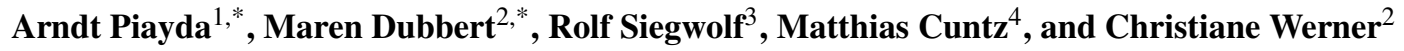 \\ ${ }^{1}$ Thünen Institute of Climate-Smart Agriculture, 38116 Braunschweig, Germany \\ ${ }^{2}$ Ecosystem Physiology, University Freiburg, 79110 Freiburg, Germany \\ ${ }^{3}$ Lab for Atmospheric Chemistry, Ecosystems and Stable Isotope Research, Paul Scherrer Institut, \\ 5232 Villingen PSI, Switzerland \\ ${ }^{4}$ UMR Ecologie et Ecophysiologie Forestières, UMR1137, INRA-Université de Lorraine, \\ Champenoux-54500 Vandoeuvre Les Nancy, 54280, France \\ *These authors contributed equally to this work.
}

Correspondence to: Arndt Piayda (arndt.piayda@thuenen.de) and Maren Dubbert (maren.dubbert@cep.uni-freiburg.de)

Received: 20 October 2016 - Discussion started: 31 October 2016

Revised: 15 March 2017 - Accepted: 23 March 2017 - Published: 5 May 2017

\begin{abstract}
The presence of vegetation alters hydrological cycles of ecosystems. Complex plant-soil interactions govern the fate of precipitation input and water transitions through ecosystem compartments. Disentangling these interactions is a major challenge in the field of ecohydrology and a pivotal foundation for understanding the carbon cycle of semiarid ecosystems. Stable water isotopes can be used in this context as tracer to quantify water movement through soilvegetation-atmosphere interfaces.

The aim of this study is to disentangle vegetation effects on soil water infiltration and distribution as well as dynamics of soil evaporation and grassland water use in a Mediterranean cork oak woodland during dry conditions. An irrigation experiment using $\delta^{18} \mathrm{O}$ labelled water was carried out in order to quantify distinct effects of tree and herbaceous vegetation on the infiltration and distribution of event water in the soil profile. Dynamic responses of soil and herbaceous vegetation fluxes to precipitation regarding event water use, water uptake depth plasticity, and contribution to ecosystem soil evaporation and transpiration were quantified.

Total water loss to the atmosphere from bare soil was as high as from vegetated soil, utilizing large amounts of unproductive evaporation for transpiration, but infiltration rates decreased. No adjustments of main root water uptake depth to changes in water availability could be observed during the experiment. This forces understorey plants to compete with adjacent trees for water in deeper soil layers at
\end{abstract}

the onset of summer. Thus, understorey plants are subjected to chronic water deficits faster, leading to premature senescence at the onset of drought. Despite this water competition, the presence of cork oak trees fosters infiltration and reduces evapotranspirative water losses from the understorey and the soil, both due to altered microclimatic conditions under crown shading. This study highlights complex soilplant-atmosphere and inter-species interactions controlling rain pulse transitions through a typical Mediterranean savannah ecosystem, disentangled by the use of stable water isotopes.

\section{Introduction}

Vegetation influences ecosystem water cycling in many ways. Rainfall is intercepted while at the same time infiltration, redistribution and translatory flow might be altered depending on rooting depths and soil structure (Bhark and Small, 2003; Dawson, 1993; Devitt and Smith, 2002; Dubbert et al., 2014c; Schwinning and Ehleringer, 2001; Tromble, 1988). For example, a dense vegetation layer can strongly reduce soil evaporation (Dubbert et al., 2014c; Wang et al., 2012). In turn, plant transpiration is controlled by soil water availability and distribution, and plant species have different abilities to use different soil water pools (i.e. surface vs. deep or ground water). Large parts of ecosystem water 
losses by transpiration strongly depend on plant functional types, stomatal regulation and leaf area index (LAI). Although studies within the last decades have emphasized the pivotal role of plant roots for soil water redistribution or the role of plant transpiration in ecosystem water losses (Caldwell, 1987), it remains a major challenge to quantify dynamic soil-vegetation-atmosphere feedbacks within the water cycle.

Stable water isotopes are widely used to trace water transfers in soils, through plants and at the soil-vegetationatmosphere interface (Werner and Dubbert, 2016; Yakir and Sternberg, 2000). Fractionation between the heavier and lighter isotopes occurs during phase changes (from liquid to gaseous, equilibrium fractionation) and movement (kinetic fractionation). This leads to different stable isotope compositions ( $\delta^{2} \mathrm{H}$ and $\left.\delta^{18} \mathrm{O}\right)$ in various water pools (i.e. rain, groundwater), along soil profiles, in different plant species and between water vapour evaporated from soil compared to water transpired by plants. These differences provide the basis for tracing water through an ecosystem. The utilization of different water pools within the soil by different plant individuals may be possible (Dawson, 1993; Volkmann et al., 2016a). Isotopes can further help to separate transpiration from soil evaporative fluxes (Dubbert et al., 2013; Yepez et al., 2003) or to study infiltration or distribution of precipitation in soils (Garvelmann et al., 2012; Rothfuss et al., 2015). Stable water isotopes have also been used to study water movement at the soil-vegetation interface (Caldwell et al., 1998). The isotopic composition of plant water uptake can be determined by sampling the "output" of the root system, for example the plant xylem, because the water isotopic signatures are usually not altered by plant water uptake (Dawson, 1993). Compared with values observed in the soil water profile, the preferential plant extraction depth or the proportional use of "event water" (i.e. singular precipitation events) can be determined. Although this method has been successfully used to identify processes such as hydraulic lift and soil water redistribution (Caldwell et al., 1998), most datasets were limited in temporal and spatial resolution (Asbjornsen et al., 2008; Kurz-Besson et al., 2006). Over the last decade, the development of field-deployable laser spectroscopy has enabled continuous measurements of water vapour and its isotopic signatures in ecosystem fluxes and atmospheric concentrations. This opens the door for large-scale assessment of the soil-vegetation-atmosphere interactions in the water cycle. In particular, these developments have enhanced the spatial and temporal resolution tremendously, furthering the understanding in the fields of plant ecophysiology (Cernusak et al., 2016) and ecosystem physiology (Dubbert et al., 2014a, c).

In the present study, we focus on disentangling the vegetation effects on soil water infiltration and distribution as well as dynamics of soil evaporation and grassland water use in a Mediterranean cork oak woodland. An irrigation experiment with $\delta^{18} \mathrm{O}$ labelled water was carried out (1) to quantify the distinct effects of tree and herbaceous vegetation on in- filtration and distribution of event water (freshly introduced water) in the soil profile and (2) to quantify the dynamic responses of soil and herbaceous vegetation fluxes to precipitation regarding event water use, plasticity of water uptake depth and contribution to ecosystem ET. The following hypotheses were tested:

I. The presence of understorey vegetation increases evapotranspirative water loss compared to bare soil but fosters infiltration due to shading.

II. The preferential root water uptake depth of understorey plants is unaffected by changes in soil water availability after rain pulses during drought.

III. Tree shading fosters the infiltration of event water and reduces evapotranspiration generating favourable soil moisture conditions for understorey plants.

\section{Material and methods}

\subsection{Study site and experimental design}

Measurements were conducted between 26 May and 6 June 2012 in an open cork oak woodland (Quercus suber L.) in central Portugal, approximately $100 \mathrm{~km}$ north-east of Lisbon $\left(39^{\circ} 8^{\prime} 17.84^{\prime \prime} \mathrm{N} 8^{\circ} 20^{\prime} 3.76^{\prime \prime} \mathrm{W}\right.$; Herdade de Machoqueira do Grou). The trees are widely spaced (209 individuals $\mathrm{ha}^{-1}$ ) with a leaf area index of 1.1 and a gap probability of 0.7 (Piayda et al., 2015).

The herbaceous layer is dominated by native annual forbs and grasses. The site is characterized by Mediterranean climate, with a 30-year long-term mean annual temperature of approximately $15.9^{\circ} \mathrm{C}$ and annual precipitation of $680 \mathrm{~mm}$ (Instituto de Meteorologia, Lisbon). We established two sites: one directly under the oak crown projected area (tree site, ts) and another one in an adjacent open area (open site, os). Two types of plots (sized $40 \times 80 \mathrm{~cm}$ ) were installed at each site: bare-soil plots with total exclusion of above- and below-ground biomass (lateral root ingrowth was prevented by vertically inserted trenching meshes around the plots; mesh diameter $<1 \mu \mathrm{m}$; Plastok, Birkenhead, UK) and understorey plots with herbaceous vegetation (four plots per site and treatment). The sites were kept vegetation free just by regular weeding. We expect no influence of the mesh on infiltration, since the plots were installed 1 year before the experiment and processes like preferential flow along the mesh are unlikely (For further details see Dubbert et al., 2013).

After a baseline observation, all plots were watered with $20 \mathrm{~mm}$ of water within $1 \mathrm{~h}$ using watering cans. The water showed an oxygen isotopic signature of $-139.5 \%$ o to trace the influence of different vegetation components on water infiltration. All plots and the surrounding soil were watered equally to avoid lateral gradients and possible differences between trenched and control plots. Thereafter, all measurements were conducted in seven diurnal cycles over the fol- 
lowing 10-12 days. The open and tree sites were watered independently, as the measurement setup did not allow highly resolved observations of all treatment plots at the same time. Environmental variables (photosynthetic photon flux density - PPFD; soil water content $-\theta$; vapour pressure deficit - vpd) were not significantly different between the first and second half of the observation period.

\subsection{Environmental variables and plant parameters}

PPFD was measured at both sites at approximately $1.5 \mathrm{~m}$ height (PPFD, LI-190SB, LI-COR, Lincoln, USA). Rainfall (ARG100 rain gauge, Campbell Scientific, Logan, UT, USA), air temperature and relative humidity ( $\mathrm{rH}, \mathrm{CS}-215$ temperature and relative humidity probe, Campbell Scientific, Logan, UT, USA) were measured and $30 \mathrm{~min}$ averages were stored by a data logger (CR10x, Campbell Scientific, Logan, UT, USA). Soil temperature (custom-built pt-100 elements) was measured at $-5 \mathrm{~cm}$ depth on vegetation and bare-soil plots at both sites, and 60 min averages were stored in a data logger (CR1000, Campbell Scientific, Logan, UT, USA; four sensors per depth and treatment). Temperature at the soil surface was manually measured on each measurement day in diurnal cycles corresponding with the gas-exchange measurements using temperature probes (GMH 2000, Greisinger electronic, Regenstauf, Germany). Volumetric soil water content $\left(\theta_{\mathrm{s}}, 10 \mathrm{~h}\right.$, Decagon, Washington, USA) was measured in $5,15,30$ and $60 \mathrm{~cm}$ depth on vegetation and bare-soil plots at both sites, and $60 \mathrm{~min}$ averages were stored in a data logger (CR1000, Campbell Scientific, Logan, UT, USA; four sensors per depth and treatment).

Living above-ground biomass of herbaceous plants was determined destructively on five randomly selected, $40 \mathrm{~cm} \times 40 \mathrm{~cm}$ plots at the beginning and end of the experiment in the open and under the trees. All green fresh aboveground plant biomass was collected, divided by species, dried $\left(60^{\circ} \mathrm{C}, 48 \mathrm{~h}\right)$ and weighed. Below-ground biomass was sampled with soil cores in 5, 15, 30 and $60 \mathrm{~cm}$ depth. Ovendried soil was sieved and root biomass was determined gravimetrically. In total, $80 \%$ of root biomass was distributed between 5 and $15 \mathrm{~cm}$ depth. Only $5 \%$ was distributed above $5 \mathrm{~cm}$ and $15 \%$ between 20 and $35 \mathrm{~cm}$ depth. Total aboveground biomass was relatively low compared to previous years (between 42 and $78 \mathrm{~g} \mathrm{~m}^{-2}$; see Fig. A1 in the Appendix) with a minimal fraction of dry biomass due to the considerable winter-spring drought in the hydrological year 2012 (Costa e Silva et al., 2015; Dubbert et al., 2014b; Piayda et al., 2014). Dry biomass from the previous season was removed from the plots at the end of summer 2011. While total above-ground biomass was similar between plots, species composition and relative dominance differed, with the open sites being dominated by Tuberaria guttata and the tree sites by grass and legume species (Dubbert et al., 2014b).

\subsection{Cavity ring-down spectrometer based gas-exchange flux and $\delta^{18} O$ measurements}

Water fluxes and isotopic composition were measured with a wavelength scanned cavity ring-down spectrometer (WSCRDS; Picarro, Santa Clara, USA) in combination with custom-built soil chambers (following the design of Pape et al., 2009) in an open gas-exchange system $(n=3$ per treatment and experimental site). Background and sampling air were measured alternately after stable values were reached. A 5 min interval average was used for the calculation of evapotranspiration (ET) and evaporation $(E)$. ET and $E$ were calculated according to von Caemmerer and Farquhar (1981). Oxygen isotope compositions of soil evaporation (bare-soil plots) as well as evapotranspiration of the understorey (vegetation plots) were estimated using a mass balance approach (Dubbert et al., 2013, 2014c):

$\delta_{E}=\frac{u_{\text {out }} w_{\text {out }} \delta_{\text {out }}-u_{\text {in }} w_{\text {in }} \delta_{\text {in }}}{u_{\text {out }} w_{\text {out }}-u_{\text {in }} w_{\text {in }}}$,

$\delta_{E}=\frac{w_{\text {out }} \delta_{\text {out }}-w_{\text {in }} \delta_{\text {in }}}{w_{\text {out }}-w_{\text {in }}}-\frac{w_{\text {in }} w_{\text {out }}\left(\delta_{\text {out }}-\delta_{\text {in }}\right)}{w_{\text {out }}-w_{\text {in }}}$,

where $u$ is the flow rate $\left(\operatorname{mol}\left(\right.\right.$ air) $\left.\mathrm{s}^{-1}\right), w$ is the mole fraction $\left(\mathrm{mol}\left(\mathrm{H}_{2} \mathrm{O}\right) \operatorname{mol}(\text { air })^{-1}\right)$ and $\delta$ is isotope value of the incoming (in) and outgoing (out) air stream of the chamber. Flow rates are measured with humid air so that conservation of dry air gives $u_{\text {in }}\left(1-w_{\text {in }}\right)=u_{\text {out }}\left(1-w_{\text {out }}\right)$, which leads to Eq. (2). The second term in Eq. (2) corrects for the increased gas flow in the chamber due to the addition of water by transpiration. In addition to isotopic signatures of soil evaporation and understorey evapotranspiration, the oxygen isotope signatures of ambient water vapour (in $9 \mathrm{~m}$ height) were measured with the cavity ring-down spectrometer (CRDS). All measurements were conducted as diurnal courses with five to six measurement points between 07:00 and 19:00 CET. For more details about the chamber design and measurement setup see Dubbert et al. (2013).

\subsection{Sampling and measurement of $\delta^{18} \mathrm{O}$ of soil and leaf water}

Soil samples for water extraction and $\delta^{18} \mathrm{O}$ analysis were taken on vegetated and bare-soil plots using a soil corer. Samples were collected from the soil surface $(0-0.5 \mathrm{~cm}$ depth), at $2,5,10,15,20$ and $40 \mathrm{~cm}$ soil depths $(n=4$ per depth and treatment), usually at midday, but on the day of irrigation directly preceding the irrigation pulse and additionally at 18:00. Mixed leaf samples of the herbaceous vegetation for water extraction were obtained in daily cycles in 2-hourly steps from 08:00 to 18:00 following a destructive sampling scheme affecting the overall amount of living biomass by less than $5 \%$. Thus, the effects of destructive sampling on observed ET fluxes during the experiment are negligible. Soil and leaf water samples were extracted on a custom-built vacuum line by cryogenic distillation. Water 
$\delta^{18} \mathrm{O}$ analysis was performed by headspace equilibration on an Isoprime IRMS (isotope ratio mass spectrometer; Elementar, Hanau, Germany) coupled via an open split connection to a microgas autosampler (Elementar, Hanau, Germany). Equilibration with $5 \% \mathrm{He}$ gas was done for $24 \mathrm{~h}$ at $20^{\circ} \mathrm{C}$. For every batch of 44 samples, three different laboratory standards were analysed. Laboratory standards were regularly calibrated against VSMOW (Vienna Standard Mean Ocean Water), SLAP (Standard Light Antarctic Precipitation) and GISP (Greenland Ice Sheet Precipitation) water standards (IAEA, Vienna). Analytical precision was $0.1 \%$.

\subsection{Partitioning of evapotranspiration}

Oxygen isotope signatures of soil evaporation were calculated using the Craig and Gordon equation (Craig and Gordon, 1965; Dubbert et al., 2013; Haverd and Cuntz, 2010):

$R_{E}=\frac{1}{\alpha_{k} \alpha^{+}(1-h)}\left(R_{\mathrm{e}}-\alpha^{+} h R_{\mathrm{a}}\right)$,

where $R_{E}$ is the isotope ratio $\left({ }^{18} \mathrm{O} /{ }^{16} \mathrm{O}\right)$ of evaporated water vapour and $R_{\mathrm{e}}$ is the isotope ratio of bulk soil water at the evaporating sites. The evaporating site is the vapour-liquid interface below which liquid transport and above which vapour transport is dominant (Braud et al., 2005). It has been shown for unsaturated soils that this site is related to a strong enrichment in soil water isotopic composition relative to the rest of the soil column and an exponential depletion in isotopic signature within few centimetres of the underlying soil due to evaporative enrichment of the remaining liquid water (Dubbert et al., 2013; Haverd and Cuntz, 2010). Thus, for $R_{\mathrm{e}}$ and temperature at the evaporating sites $\left(T_{\mathrm{e}}\right)$, temperature and oxygen isotope signatures of bulk soil water were measured along the soil profile and those values along the soil profile were used where the strongest enrichment in bulk soil $\delta^{18} \mathrm{O}$ could be detected (residual soil water volumetric content was only $1 \%$ and therefore neglected). $R_{\mathrm{a}}$ is the isotope ratio of ambient water vapour, $\alpha_{k}$ is the kinetic fractionation factor, $\alpha^{+}$is the water vapour equilibrium fractionation factor $\left(\alpha_{k}\right.$ and $\alpha^{+}>1$; see Majoube (1971); Merlivat (1978); for the formulation of $\alpha_{k}=\alpha_{\text {diff }}^{n k}$, see Mathieu and Bariac, 1996). $h$ is the relative humidity normalized to $T_{\mathrm{e}} . R_{E}$ can then be transferred to delta notation as $\delta=R_{E}-1 \cdot 1000$.

Although direct estimates of $E$ and $\delta^{18} \mathrm{O}_{E}$ were available for bare-soil plots, vegetation depresses $E$ and also influences $\delta^{18} \mathrm{O}_{E}$, for example due to different isotopic signatures of soil water and also temperature in bare-soil and vegetated soil patches (Dubbert et al., 2013). Therefore, bare-soil plots only served to validate the Craig and Gordon equation because on bare-soil plots $E$ contributes entirely to the evaporative flux and could be tested against modelling results. Finally, the Craig and Gordon equation was used to calculate $\delta^{18} \mathrm{O}_{E}$ of vegetation plots.

The oxygen isotope signature of transpired water vapour $\delta^{18} \mathrm{O}_{T}$ was calculated based on the isotopic signature of bulk leaf water $\delta^{18} \mathrm{O}_{L}$ using the Craig and Gordon equation (Eq. 3) instead of measuring xylem or source water isotopic signatures and modelling $\delta^{18} \mathrm{O}_{L}$ of leaf water at the evaporating sites. This was done due to the lack of suberized/lignified plant parts in the herbaceous vegetation. The isotopic signature at the evaporating site $\delta^{18} \mathrm{O}_{\mathrm{e}}$ was thus estimated by

$\delta^{18} \mathrm{O}_{\mathrm{e}}=\frac{\delta^{18} \mathrm{O}_{L} \wp}{1-e^{-\wp}}$ with the Péclet number $\wp=\frac{T L_{\mathrm{eff}}}{C D}$,

where $L_{\text {eff }}$ is the effective path length of water movement in the leaf mesophyll, which we assumed to be $0.05 \mathrm{~m}, C$ is the molar water concentration $\left(55.6 \times 10^{3} \mathrm{~mol} \mathrm{~m}^{-3}\right)$ and $D$ is the tracer diffusivity in liquid water $\left(2.66 \times 10^{-9} \mathrm{~m}^{2} \mathrm{~s}^{-1}\right)$. $T$ was estimated iteratively with Eq. (5) using ET as an initial value. Convergence was generally reached after five iterations. Small differences in isotopic compositions were found compared to a direct use of $\delta^{18} \mathrm{O}_{L}$ in Eq. (3), which were not significant for the results shown in this work.

Finally, the contribution of $T$ to ET, $f t=T / \mathrm{ET}$, can be estimated based on measured understorey $\delta^{18} \mathrm{O}_{\mathrm{ET}}$ and modelled soil $\delta^{18} \mathrm{O}_{E}$ and herbaceous $\delta^{18} \mathrm{O}_{T}$ (Moreira et al., 1997; Yakir and Sternberg, 2000):

$f t=\frac{\delta^{18} \mathrm{O}_{\mathrm{ET}}-\delta^{18} \mathrm{O}_{E}}{\delta^{18} \mathrm{O}_{T}-\delta^{18} \mathrm{O}_{E}}$.

This approach is based on the assumption that the isotopic signature of evapotranspiration is a mixing ratio of not more than the two sources (evaporation and transpiration) and that no water vapour is lost other than by the mixing of the two sources with the atmospheric pool (i.e. no condensation).

\subsection{Event water partitioning}

Event water describes the amount of water in ecosystem pools or fluxes that originates from a certain rain event. To calculate the amount of event water in volumetric soil water content $\theta$ that originates from the isotopically labelled watering event, the following linear two-source mixing model was used:

$f_{\theta, \text { eve }}=\frac{\delta^{18} \mathrm{O}_{\theta}-\delta^{18} \mathrm{O}_{\theta, \text { pre }}}{\delta^{18} \mathrm{O}_{\mathrm{eve}}-\delta^{18} \mathrm{O}_{\theta, \text { pre }}}$,

where $f_{\theta \text {,eve }}$ is the fraction of rain event water in $\theta$ at a certain time after the event, $\delta^{18} \mathrm{O}_{\theta}$ is the stable isotope ratio in $\theta$ at a certain time after the event, $\delta^{18} \mathrm{O}_{\theta \text {,pre }}$ is the stable isotope ratio of soil water before the rain event and $\delta^{18} \mathrm{O}_{\text {eve }}$ is the stable isotope ratio of the precipitation event water. The model assumes no fractionation of rain event water during infiltration and was solved separately for each depth. Contributions of infiltrated event water to evaporation fluxes from soil and transpiration fluxes from plant surfaces were calculated analogously: 
$f_{E, \text { eve }}=\frac{\delta^{18} \mathrm{O}_{E}-\delta^{18} \mathrm{O}_{E, \mathrm{pre}}}{\delta^{18} \mathrm{O}_{E, \text { eve }}-\delta^{18} \mathrm{O}_{E, \mathrm{pre}}}$,

$f_{T, \text { eve }}=\frac{\delta^{18} \mathrm{O}_{T}-\delta^{18} \mathrm{O}_{T, \text { pre }}}{\delta^{18} \mathrm{O}_{T, \text { eve }}-\delta^{18} \mathrm{O}_{T, \text { pre }}}$,

where $f_{E \text {,eve }}$ and $f_{T \text {,eve }}$ are the fractions of rain event water in evaporation $E$ and transpiration $T . \delta^{18} \mathrm{O}_{E \text {,pre }}$ and $\delta^{18} \mathrm{O}_{E \text {,eve }}$ are the isotopic compositions of evaporation calculated with Eq. (3), assuming that the source water isotopic composition equals either $\delta^{18} \mathrm{O}_{\theta \text {,pre }}$ at the evaporative site or $\delta^{18} \mathrm{O}_{\text {eve }} . \delta^{18} \mathrm{O}_{T \text {, pre }}$ and $\delta^{18} \mathrm{O}_{T \text {,eve }}$ are the isotopic compositions of transpiration calculated with Eqs. (3) and (4), assuming that the source water isotopic composition equals either bulk leaf composition before watering $\delta^{18} \mathrm{O}_{L \text {,pre }}$ or $\delta^{18} \mathrm{O}_{\text {eve }}$.

\subsection{Root water uptake}

The preferential depth of root water uptake by plants along the soil depth was estimated via a linear three-source model. Therefore, the isotopic composition of transpiration $\delta^{18} \mathrm{O}_{T}$ calculated with Eqs. (3) and (4) from three independent observations of leaf water compositions $\delta^{18} \mathrm{O}_{L}$ were compared with three independent solutions for isotopic transpiration composition $\delta^{18} \mathrm{O}_{T}$ of Eq. (3), each assuming the current water source for transpiration originating only from an observed depth $(d 1=-5 \mathrm{~cm}, d 2=-15 \mathrm{~cm}, d 3=-30 \mathrm{~cm})$. Soil depth above and below $d 1$ to $d 3$ showed negligible root density in the profile and could therefore be excluded from the model. The three possible source fluxes are related to the resulting transpiration flux mixture via the following system of equations (compare, e.g., Philips et al., 2005):

$$
\begin{aligned}
\delta^{18} \mathrm{O}_{T 1} & =f_{T, d 1} \cdot \delta^{18} \mathrm{O}_{T 1, d 1}+f_{T, d 2} \cdot \delta^{18} \mathrm{O}_{T 1, d 2} \\
& +f_{T, d 3} \cdot \delta^{18} \mathrm{O}_{T 1, d 3}+\varepsilon_{1}, \\
\delta^{18} \mathrm{O}_{T 2} & =f_{T, d 1} \cdot \delta^{18} \mathrm{O}_{T 2, d 1}+f_{T, d 2} \cdot \delta^{18} \mathrm{O}_{T 2, d 2} \\
& +f_{T, d 3} \cdot \delta^{18} \mathrm{O}_{T 2, d 3}+\varepsilon_{2}, \\
\delta^{18} \mathrm{O}_{T 3} & =f_{T, d 1} \cdot \delta^{18} \mathrm{O}_{T 3, d 1}+f_{T, d 2} \cdot \delta^{18} \mathrm{O}_{T 3, d 2} \\
& +f_{T, d 3} \cdot \delta^{18} \mathrm{O}_{T 3, d 3}+\varepsilon_{3} \\
1 & =f_{T, d 1}+f_{T, d 2}+f_{T, d 3},
\end{aligned}
$$

where $f_{T, d}$ denotes the fraction of source water contribution from depths $d 1$ to $d 3$ to the transpiration flux. The system was solved for $f_{T, d 1}$ to $f_{T, d 3}$ using a shuffled complex evolution algorithm (Duan et al., 1992) minimizing a multiobjective cost function (Duckstein, 1981) combining the error terms $\varepsilon_{1}$ to $\varepsilon_{3}$ for each time step.

\subsection{Error propagation}

All results are reported as replicate mean with associated standard error to achieve comparability between different

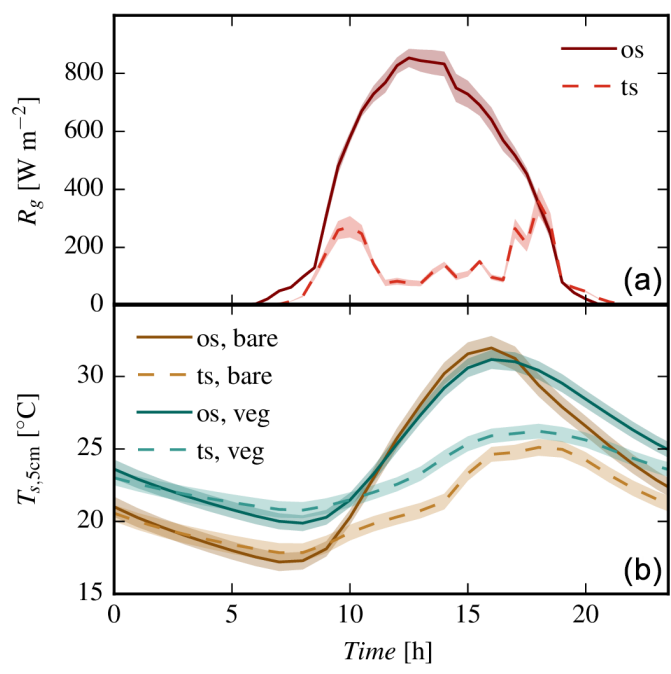

Figure 1. Daily cycles, averaged over the experiment period, of (a) global radiation $R_{\mathrm{g}}$ at $1.5 \mathrm{~m}$ height and (b) soil temperature $T_{\mathrm{S}, 5 \mathrm{~cm}}$ at $5 \mathrm{~cm}$ depth under bare soil (bare) or vegetation cover (veg). Observations at open sites between tree crowns (os) and shaded sites beneath tree crowns (ts) are shown. Uncertainty bands display standard error.

sample sizes. All model calculations were applied to single replica and averaged afterwards. Observed effects were considered statistically different when no overlap of standard errors was observed.

\section{Results}

\subsection{Environmental and soil conditions}

Tree cover significantly influenced diurnal courses of incoming global radiation $R_{\mathrm{g}}$ during the daytime at the sites. Strong reductions in $R_{\mathrm{g}}$ between 09:00 and 18:00 reduced the daily sum of energy input $\sum R_{\mathrm{g}}$ by $17.1 \mathrm{MJ} \mathrm{m}^{-2} \mathrm{~d}^{-1}$ at the open sites (os) compared to the tree sites (ts) (Fig. 1). However, air temperature and relative humidity were very similar in the open area and below trees with mean values around $66 \%$ and $19^{\circ} \mathrm{C}$ throughout the experiment. Similar to $R_{\mathrm{g}}$, the amplitude of daily mean soil temperatures $T_{\mathrm{S}}$ in the upper soil layer was smaller at tree sites (bare: $7.4^{\circ} \mathrm{C}$; veg: $5.5^{\circ} \mathrm{C}$ ) than in the open area $\left(14.9\right.$ and $11.3^{\circ} \mathrm{C}$ for bare and vegetated soils, respectively, Fig. 1). In contrast, understorey vegetation cover reduced the soil temperature only by $2-3.6^{\circ} \mathrm{C}$ at both sites.

Soil moisture $\theta$ prior to the irrigation pulse ranged from 5 to $10 \%$ (Fig. 3), which is low compared to the annual average but typical for the observation period at the end of May and the beginning of the dry season. Systematically, lower soil moisture $\theta$ at depths below $20 \mathrm{~cm}$ could be observed at the tree sites located close to trees compared to open sites, 


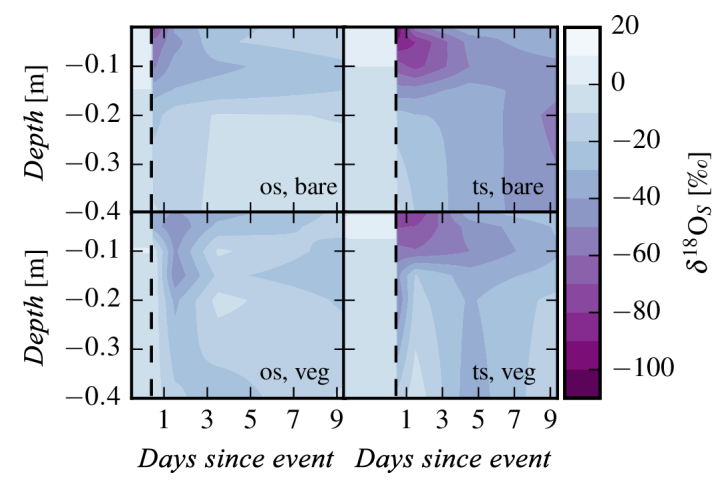

Figure 2. Mean daily isotopic composition of soil water $\delta^{18} \mathrm{O}_{S}$ during experiment under bare soil (bare) or vegetation cover (veg) at open sites between tree crowns (os) and shaded sites beneath tree crowns (ts). Dashed lines mark time of watering event. Interpolation method: linear. The standard error for soil isotopic composition during the experiment amounts on average to $1.4 \%$ in natural abundance.

whereas the upper soil layers showed comparable values for all sites prior to the experiment.

\subsection{Oxygen isotope signatures of ecosystem water pools}

Stable oxygen isotope composition of soil water $\delta^{18} \mathrm{O}_{S}$ for all plots and all depths ranged between -7.3 and $10.1 \%$ o before the irrigation. Compared to the very depleted irrigation water signature of $-139.5 \%$, only a small enrichment in $\delta^{18} \mathrm{O}_{S}$ of on average $0.4 \%$ at the open sites compared to the tree sites was found and $2.9 \%$ enrichment of bare soil compared to vegetation plots preliminary to the watering (Fig. 2). Irrigation caused a strong depletion of $\delta^{18} \mathrm{O}_{S}$ with a peak only $1 \mathrm{~h}$ after irrigation in the upper soil layer. Strongest depletion of $\delta^{18} \mathrm{O}_{S}$ values were found at tree sites on bare-soil plots $\left(\delta^{18} \mathrm{O}_{S}=-106.06 \%\right.$ o $)$ and tree sites with vegetation cover $\left(\delta^{18} \mathrm{O}_{S}=-85.1 \%\right.$ ), whereas the open sites showed weaker maximum depletions of $\delta^{18} \mathrm{O}_{S}=-79.9 \%$ 。 and $\delta^{18} \mathrm{O}_{S}=-49.4 \%$ on bare-soil and vegetation plots, respectively. The 9 days following the irrigation event were characterized by a steady increase in $\delta^{18} \mathrm{O}_{S}$, which was slightly depleted compared to pre-event $\delta^{18} \mathrm{O}_{S} 9$ days after irrigation. In addition to the absolute differences in peak $\delta^{18} \mathrm{O}_{S}$ between sites, the depletion in $\delta^{18} \mathrm{O}_{S}$ was maintained for a longer period at tree sites (Fig. 2).

Oxygen isotope signatures of soil evaporation and leaf water as well as transpired water vapour (Fig. 4) showed an immediate response to the irrigation pulse, with peak depletion only $1 \mathrm{~h}$ after labelling for soil evaporation and $3 \mathrm{~h}$ for leaf water and transpired vapour. Subsequently, an exponential rise to pre-event isotope values could be observed in all pools. Depletion in $\delta^{18} \mathrm{O}_{E}$ of soil evaporation was much stronger compared to $\delta^{18} \mathrm{O}_{T}$ of plant transpiration (and leaf water $\left.\delta^{18} \mathrm{O}_{L}\right) \cdot \delta^{18} \mathrm{O}_{E}$ of soil evaporation and evapotranspiration $\delta^{18} \mathrm{O}_{\mathrm{ET}}$ were both more reduced at the tree sites com-

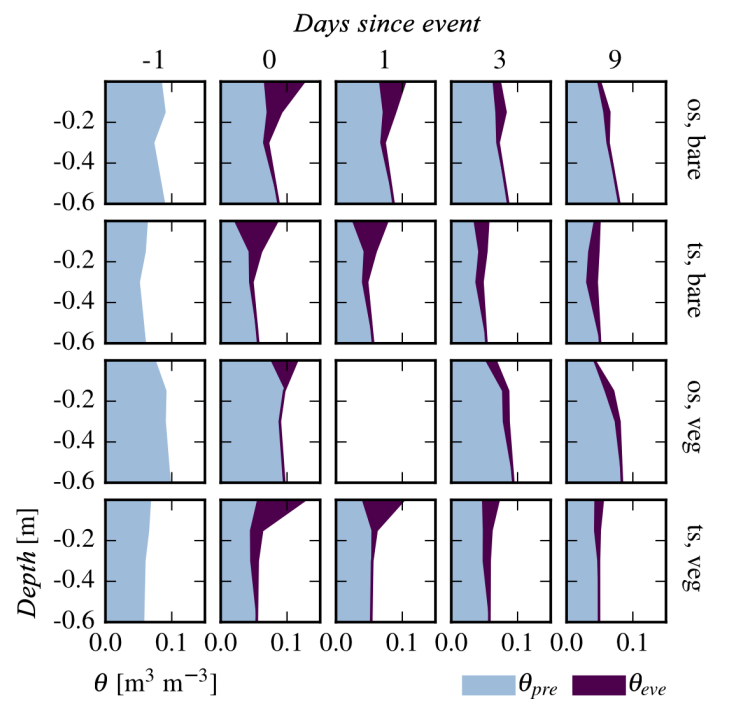

Figure 3. Mean daily soil water content $\theta$ along soil depth separated into pre-event soil water content $\theta_{\text {pre }}$ and infiltrated event soil water content $\theta_{\text {eve }}$. Observations are displayed for plots under bare soil (bare) or vegetation cover (veg) at open sites between tree crowns (os) and shaded sites beneath tree crowns (ts). Numbers at the top mark days since the watering event. Uncertainties for soil moisture observations during the experiment amount on average to $2.3 \%$ vol. propagated from the observations. Event water partitioning for day 1 on open, vegetated plots needed to be omitted due to inadequate field data quality.

pared to the open sites. A similarly strong vegetation effect could be seen between $\delta^{18} \mathrm{O}_{E}$ on bare-soil plots in comparison to understorey vegetation plots.

\subsection{Infiltration and distribution of event water}

Daily mean soil moistures $\theta$ throughout the experiment were characterized by the ongoing drought at all sites (Fig. 3). Watering the plots with $20 \mathrm{~mm}$ increased mean daily soil moisture $\theta$ in the upper layers only by 2 to $6 \%$ vol. and had no effect on deeper soil layers. However, partitioning event water fractions revealed an extensive replacement of old, pre-event water with new event water up to $4 \%$ vol. and even down to depths below $-30 \mathrm{~cm}$ (Fig. 3), in particular on bare-soil plots. Systematically increased infiltration and deepened distribution of event water was observed at tree sites compared to open sites. In the course of the experiment, soil moistures returned to pre-event values and below. The decrease in event water was stronger than that of pre-event water, leaving nearly no trace 9 days after the watering.

\subsection{Event water use by plant transpiration}

While pre-event $E$ on bare-soil plots was lower than ET on vegetation plots at both the open and tree sites, $E$ and ET peaked equally with roughly $3.3 \mathrm{mmol} \mathrm{m}^{-2} \mathrm{~d}^{-1}$ at the open sites. However, at the tree sites the post-event peak of $E$ at 


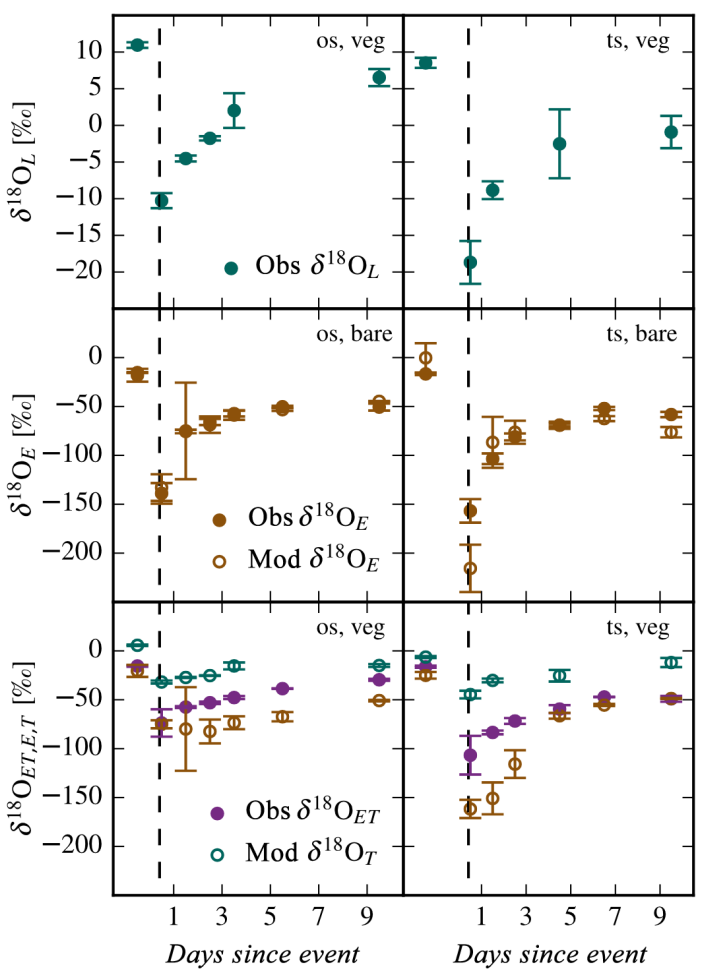

Figure 4. Mean daily isotopic composition of bulk leaf water $\delta^{18} \mathrm{O}_{L}$, soil evaporation $\delta^{18} \mathrm{O}_{E}$, plant transpiration $\delta^{18} \mathrm{O}_{T}$ and combined evapotranspiration $\delta^{18} \mathrm{O}_{\mathrm{ET}}$ from bare-soil (bare) or vegetation plots (veg) at open sites between tree crowns (os) and shaded sites beneath tree crowns (ts). Filled dots represent observed values (obs); hollow dots represent modelled values (mod). Dashed lines mark time of watering event. Uncertainty bars display standard error.

bare-soil plots $\left(2.1 \pm 0.1 \mathrm{mmol} \mathrm{m}^{-2} \mathrm{~d}^{-1}\right)$ was higher than ET at vegetation plots $\left(1.5 \pm 0.2 \mathrm{mmol} \mathrm{m}^{-2} \mathrm{~d}^{-1}\right)$. Moreover, the peak of ET at both sites was shifted by $24 \mathrm{~h}$ compared to $E$ and occurred only 2 days after irrigation (Fig. 5). Following peaks in $E$ and ET, evapotranspiration losses declined exponentially to pre-event values 3 days after irrigation on all sites.

Partitioning ET on vegetation plots at both sites into soil $E$ and plant transpiration $T$ revealed that the time shift of the response of the ET flux compared to bare-soil plots $E$ was caused solely by a slower reaction of $T$ to the irrigation pulse. Throughout the experiment the proportion of $T$ to ET ranged from 9 to $59 \%$ at open sites and 17 to $66 \%$ at shaded sites.

Event water fraction in soil evaporation $f_{E \text {,eve }}$ and plant transpiration $f_{T, \text { eve }}$ differed considerably with $T$ utilizing only a peak of $12 \%$ of the event water while $E$ is fed up to $62 \%$ by event water following irrigation (Fig. 6). Nine days after the irrigation pulse, the event water contribution of $T$ and $E$ converged on average to $10 \%$ of the respective flux and differences between $f_{E \text {,eve }}$ and $f_{T \text {,eve }}$ faded. Event

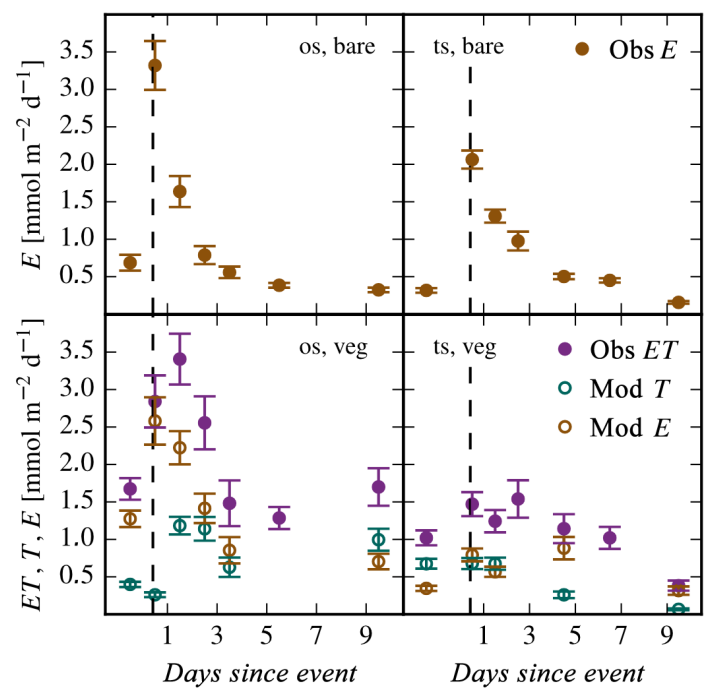

Figure 5. Mean daily flux rates of soil evaporation $E$, plant transpiration $T$, and combined evapotranspiration ET from bare-soil (bare) or vegetation plots (veg) at open sites between tree crowns (os) and shaded sites beneath tree crowns (ts). Filled dots represent observed values (obs); hollow dots represent modelled values (mod). Dashed lines mark time of watering event. Uncertainty bars display standard error.

water lost by soil evaporation $f_{E \text {,eve }}$ showed no significant differences between open and tree sites nor between baresoil plots and vegetated plots except on the day of watering on the open vegetation plot. Here, $f_{E \text {,eve }}$ only reached about $25 \%$, corresponding to the limited availability of event water in the soil (Fig. 2). No significant differences could be observed between $f_{T \text {,eve }}$ on open and vegetation plots.

\subsection{Preferential root water uptake depth}

Prior to the irrigation pulse we refrained from calculations of preferential root water uptake depth, since the differences in $\delta^{18} \mathrm{O}_{S}$ along soil depth were too small (see above) for a sufficient, accurate prediction power to solve the equation system (Eq. 9), and we derived significant $f_{T, d}$. Following the label pulse, soil water uptake by plants was located solely at soil depths around $30 \mathrm{~cm}$ with no change in time or between open and tree sites despite a small uptake of water for transpiration from soil layers around $-15 \mathrm{~cm}$ on day 0 and 1 after watering (Fig. 7).

\section{Discussion}

\subsection{Infiltration and distribution of event water}

Mosaic patterns of vegetation cover by understorey plants and trees are characteristic for savannah-type ecosystems (Belsky, 1994; Greig-Smith, 1979). Different vegetation cover is known to alter soil hydrological conditions and mi- 


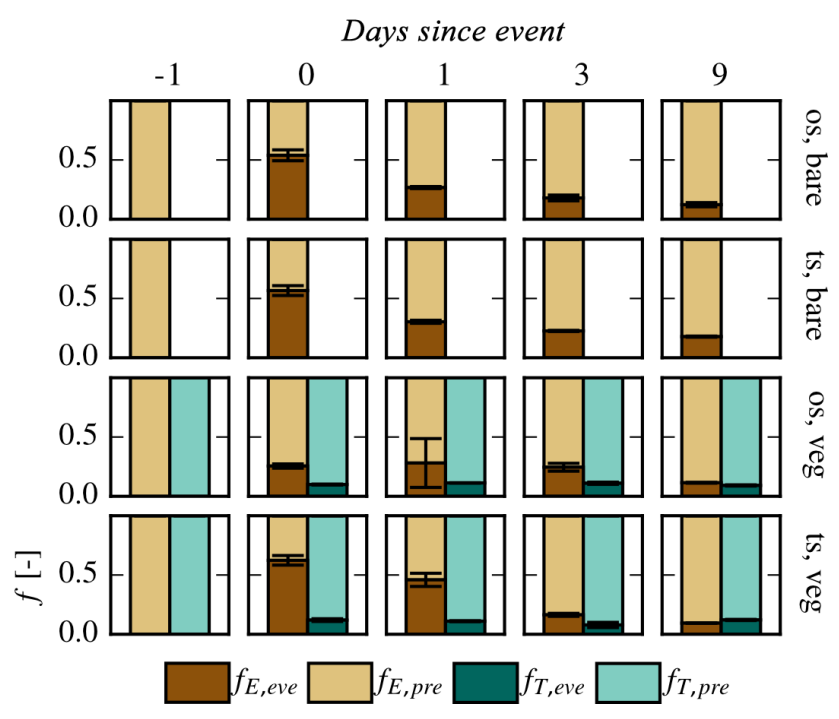

Figure 6. Mean daily fractions $f$ of event water (eve) and pre-event water (pre) in soil evaporation $E$ and plant transpiration $T$ from bare-soil (bare) or vegetation plots (veg) at open sites between tree crowns (os) and shaded sites beneath tree crowns (ts). Numbers at the top mark days after watering event. Uncertainty bars display standard error.

croclimate (Scholes and Archer, 1997), which in turn have effects on vegetation cover and ecosystem sustainability in future climate change scenarios (Breman and Kessler, 1999; Pueyo et al., 2012). The infiltration of event water into soil in this ecosystem is strongly altered by understorey cover and tree shading. The vegetation cover of understorey plants reduced infiltration on average by $24 \%$ compared to bare soil (Fig. 3), which clearly contradicts part two of hypothesis I. The reason can be found in interception, subject to instantaneous plant and litter surface evaporation before the first flux observations, which took place $1 \mathrm{~h}$ after watering. This water uptake limitation could neither be compensated for by plant roots, breaking the crust formations which can be observed in the field and are common for Mediterranean soils and limiting the hydraulic conductivity of top soils (Eldridge et al., 2010; Goldshleger et al., 2002; Maestre et al., 2002), nor by beneficial shading effects by the above-ground biomass, which did not significantly reduce the soil surface temperatures (Fig. 1) and thus the evaporative demand of boundary layers. The observed infiltration on the day of watering can further be regarded as insignificantly affected by understorey root water uptake, which is confirmed by low transpiration fluxes on the day of watering (Fig. 5). This is in contrast to previous studies, which reported beneficial effects of plant cover on daily sums of infiltration during the same period at the onset of drought in 2011 (Dubbert et al., 2014c). However, Dubbert et al. (2014c) only observed precipitation events of light intensity during the period of interest. The present study reports on high-intensity precipitation events. Furthermore, above-ground vegetation cover and

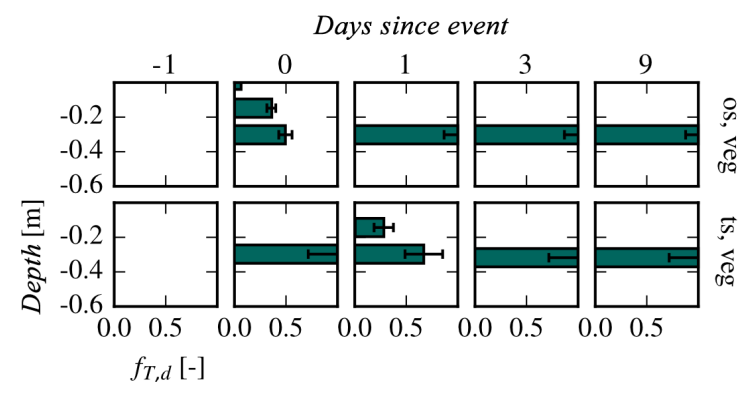

Figure 7. Mean daily fractions of root water uptake $f_{T, d}$ of understorey plants for modelled soil depths. Numbers at the top mark days after watering event. Uncertainty bars display standard error.

biomass were reduced by 55 and $30 \%$, respectively, owing to the additional severe winter-spring drought in 2012. It is thus likely that such a drastic reduction in understorey canopy cover eliminates much of the beneficial understorey effects on the ecosystem water balance. This unexpected turn in effect direction with increasing precipitation intensity, which depends on vegetation cover and atmospheric evapotranspirative demand, potentially plays a strong role for the water balance of the ecosystem in the course of ongoing climate change scenarios since the occurrence of extreme precipitation events is expected to increase (IPCC, 2013).

Tree shading had a tremendous impact on the microclimate above understorey plant and soil surfaces, but effects on infiltration amount could only be observed on vegetated plots. Reductions in the daily sum of global radiation $\sum R_{\mathrm{g}}$ by $72 \%$ and daily peak soil temperatures $T_{\mathrm{S}, 5 \mathrm{~cm}}$ up to $22 \%$ (Fig. 1) generated favourable conditions. Limited instantaneous evaporation from plant surfaces as described above led to $71 \%$ higher infiltration amounts (Fig. 3), whereas the high infiltration amounts on bare-soil plots were unaffected by tree shading. This confirms part one of hypothesis III on vegetated plots. Previous studies reported similar, positive feedbacks of tree cover for the hydrological cycle in savannah-type ecosystems related to shading effects (Eldridge and Freudenberger, 2005). Effects of altered soil hydraulic properties beneath tree crowns, like the amount of preferential flow fostering infiltration (Bargués Tobella et al., 2014), could not be identified in this study. Supporting findings are given by Bhark and Small (2003) and D'Odorico and Porporato (2006). Considering the projected shading by crown cover of the tree layer (minimum of $30 \%$ at noon, increasing during the rest of the day; Piayda et al., 2015), the infiltration enhancement has potentially large benefits for the ecosystem level. A previous study of David et al. (2006) under comparable climatic and stand density conditions estimated only minor interception losses of $8 \%$ with respect to total canopy throughfall due to low canopy cover typical for cork oak systems. However, the integral balance of canopy interception losses, increased infiltration and other benefits of tree cover (compare Joffre and Rambal, 1993, and Dub- 
bert et al., 2014c) in this ecosystem could not be analysed in this study and need further investigations with regard to tree density and age.

The subsurface distribution of soil water $\theta$ was systematically lower at depths below $20 \mathrm{~cm}$ at tree sites compared to open sites (Fig. 3). This clearly indicates the enhanced water extraction by tree roots, similar to the results of Dubbert et al. (2014b). The observed pattern could not be changed by the event water pulse of $20 \mathrm{~mm} \mathrm{~h}^{-1}$, equal to a rain event of high intensity at this site. That explains the intense drought stress understorey plants suffer during the transition period from moist spring to dry summer, leading to earlier dieback under tree cover (Dubbert et al., 2014b; Moreno, 2008), and it contradicts part two of hypothesis III. The depth distribution of event water is very similar on bare-soil plots that show an overall deeper infiltration of more water than the vegetated plots, caused by the higher infiltration amounts shown before. This negative effect could partially be compensated for by higher infiltration amounts below tree shading but the water was consumed by tree water uptake from deeper depths within 1 day. During these dry conditions, pre-event water is located in small pores under high matrix potentials. Infiltrating event water partially displaced pre-event water downwards (Fig. 3) and additionally filled larger pores in the top soil. Thus, event water is more subject to evaporation due to lower matrix potentials in bigger pores than pre-event water. This observation is supported by a rapid decrease in event water content throughout the experiment.

\subsection{Dynamic responses of event water use and plasticity of water uptake depth}

The successful biomass production of herbaceous vegetation depends highly on soil water availability in upper soil layers hosting the root system. Occasional precipitation events control the soil water regime (Porporato et al., 2004), and these are prone to substantial changes in future climate change scenarios through stronger short-term fluctuations of drought events (IPCC, 2013). Thus, a rapid adaptation of preferential root water uptake depth is crucial. This is particularly important for herbaceous vegetation in order to maximize the utilization of different soil water pools for a successful seed production, longevity and inter-species competition (Ehleringer and Dawson, 1992; Rodriguez-Iturbe, 2000). It could be clearly shown that understorey transpiration $T$ responded slower to an incoming precipitation pulse than soil evaporation $E$, with a time lag of about $24 \mathrm{~h}$. ET on vegetated plots and $E$ on bare-soil plots showed equally high peaks and a comparable decline until the end of the experiment, providing no evidence for higher water losses due to the presence of understorey and contradicting part one of hypothesis I. During the entire experiment, $E$ was the dominant flux on both tree and open sites, with a comparable contribution of transpiration $T$ to evapotranspiration ET of 36 and $41 \%$ (Fig. 5), respectively. This small loss of transpiration water originates on one hand from the longer time response lag of $T$ and on the other hand from only little event water reaching deeper soil layers, where understorey plants have their main root water uptake depth. Event water use of the understorey vegetation was overall low, since no shift of root water uptake depth could be observed within the 9 days of the experiments (Fig. 7) leading to comparably small isotopic depletion of bulk leaf water and transpiration (Fig. 4), which supports hypothesis II. This is in agreement with previous findings where annual savannah species were not readjusting their water extraction depth fast enough in order to exploit precipitation water more efficiently (Asbjornsen et al., 2008; Kulmatiski and Beard, 2013). More importantly, during that period of the year the dry conditions in the upper soil layers forces understorey plants in the direct vicinity of trees to compete for soil water at lower depths where the trees have their roots (i.e. tree sites). This observation clearly contradicts the widely discussed two-layer hypothesis, proposing independent ecological niches for root water uptake of trees and understorey plants in savannahs in order to avoid competition (Hipondoka et al., 2003; Holdo and Planque, 2013; Kulmatiski et al., 2010; Walter et al., 1971). Moreover, exponential soil profiles of plant available nitrogen cause a coupled water and nutrient competition between herbs and trees in this ecosystem during spring (Dubbert et al., 2014b). Modelling studies of, e.g., Nippert et al. (2015) already suggested that understorey plants do not exploit all accessible soil layers (including the top layers with high drought risk) in order to maximize water availability. Lower but more resilient production is achieved instead by limiting root growth and water uptake to deeper depths, which could be confirmed by this study. Additionally, it has to be considered that the herbaceous vegetation already reached its growth peak when the experiment was conducted, and thus maximizing root water uptake might not be a priority for the understorey community past the growth peak and during seed production. Dubbert et al. (2014b) showed that the understorey community is strongly adapted on a small spatial scale to the presence of oak trees regarding its species composition and overall vegetation period length. This is also observed in this study, with grasses dominating the understorey community below the trees and forbs dominating in open areas (Fig. A1). Effectively this leads to an earlier seed production and senescence of less drought-tolerant grasses in water competition with trees and a longer vegetation period of drought-tolerant native forbs (i.e. Tuberaria guttata or Tolpis barbata) in open areas. Consequently, while understorey species in the open area remained a net sink for carbon during the entire experiment, the understorey community below the trees was on the verge of senescence and turned into a net source of carbon by the last experimental date (Fig. A2), providing an additional explanation for the site-specific differences in transpiration rate in response to event water (Fig. 5).

Recently, Volkmann et al. (2016a) used a similar flux or isotope approach to test the widespread dogma that plant wa- 
ter uptake depth is primarily controlled by root density distribution. While grassland species did not strongly alter their uptake pattern during the measurement campaign, their water uptake depth profile was not in accordance with their root density distribution, with $85 \%$ in the upper $10 \mathrm{~cm}$ of the soil profile. This clearly indicates that adapting the water uptake to soil water availability plays a role, but probably on longer timescales than what we observed during the 10-day experiment. The development of membrane-based in situ methods of soil water (Gaj et al., 2016; Rothfuss et al., 2015; Volkmann et al., 2016a) and xylem sap sampling (Volkmann et al., 2016b) and transpiration (Dubbert et al., 2014a, 2017) will advance the studies of dynamic changes in ecohydrological soil-vegetation feedbacks in the future. Furthermore, the coupling of isotope laser spectroscopes to gas-exchange chambers and soil or xylem equilibration probes overcomes the costly and time-consuming classical destructive sampling methods. Recent studies (Orlowski et al., 2013) showed significant isotopic deviations between actual soil water that is available for the plants and water that is cryogenically extracted from soil samples depending on soil type. While we did not observe this in sandy soils at our study site, these effects might severely hamper the usefulness of destructive soil sampling techniques in clay or loam soils. The newly developed in situ techniques will thus facilitate cost-effective measurements of soil or xylem isotopic signatures with the highest resolution, enhancing our capacity to study the dynamics of soil water infiltration, of the uptake of water by plants and of the partitioning of evapotranspiration.

\section{Conclusion}

In this study, the various interactions between understorey vegetation and trees of a Mediterranean cork oak woodland affecting the ecosystem water flows could be quantified. The immediate on-site determination (with CRDS) of the isotope ratios from different soil and ecosystem compartments in combination with in situ sampling methods enhanced the resolution, precision and reliability of our results. This facilitated the tracing of the fate of rain pulse transitions through a typical Mediterranean savannah ecosystem using stable water isotopes.
Regardless of the presence of vegetation, the total evapotranspirative water loss of soil and understorey remains unchanged, but infiltration rates decreased by $24 \%$ (hypothesis I rejected). Still, the amount of unproductive evaporation is largely reduced in favour of transpiration. Adjustments of main root water uptake depth to changing soil water availability after rain pulses could not be observed (hypothesis II supported). Consequently, the understorey plants could not utilize the applied precipitation of $20 \mathrm{~mm}$. Hence, these understorey plants were forced into water competition with trees, rooting at deeper soil layers. The crown shading of cork oak trees altered microclimatic conditions, thus fostering infiltration and considerably reducing understorey and soil evapotranspiration (hypothesis III, part one supported). Despite these benefits, understorey plants in the immediate vicinity of trees suffer from systematically lower soil moistures in deeper layers leading to premature senescence at the onset of drought (hypothesis III, part two rejected).

Data availability. The underlying research data can be requested from the corresponding authors via email. 


\section{Appendix A}

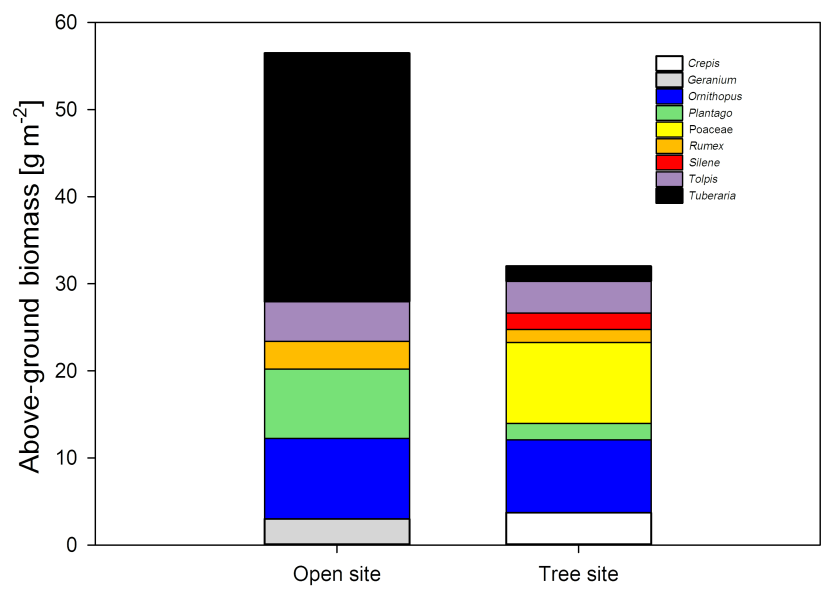

Figure A1. Above-ground biomass on vegetated plots during the experiment time given for each genus. Standard errors are not given for the sake of clarity but amount on average to $30 \%$ of displayed genus biomass.

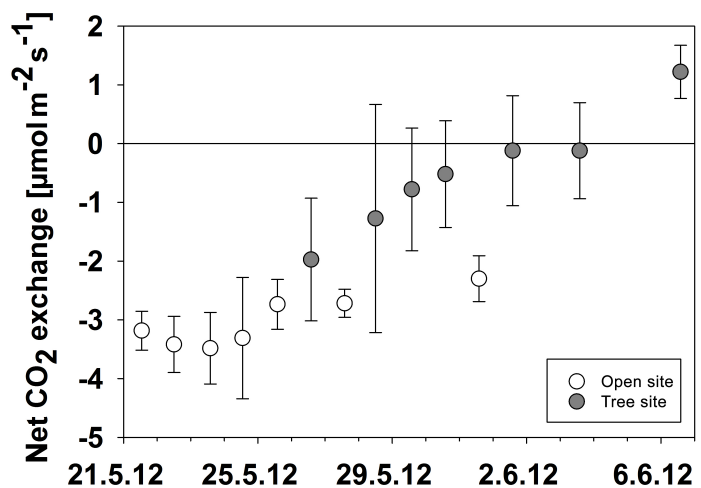

Figure A2. Mean midday net ecosystem exchange (NEE) of the understorey vegetation at the open site (white circles) and the tree site (dark grey circles). 
Author contributions. Arndt Piayda and Maren Dubbert contributed equally to experimental work, data analysis and writing the paper. Matthias Cuntz contributed to data analysis, and he, Rolf Siegwolf and Christiane Werner read and provided feedback on the paper.

Competing interests. The authors declare that they have no conflict of interest.

Acknowledgements. We gratefully acknowledge excellent help in the laboratory by Ilse Thaufelder. Funding for this study was provided by the DFG grants to Christiane Werner and Matthias Cuntz (WATERFLUX Project: no. WE 2681/6-1, no. CU 173/2-1), as well as Maren Dubbert (no. DU 1688/1-1).

Edited by: X. Wang

Reviewed by: two anonymous referees

\section{References}

Asbjornsen, H., Shepherd, G., Helmers, M., and Mora, G.: Seasonal patterns in depth of water uptake under contrasting annual and perennial systems in the Corn Belt Region of the Midwestern US, Plant Soil, 308, 69-92, 2008.

Bargués Tobella, A., Reese, H., Almaw, A., and Bayala, J.: The effect of trees on preferential flow and soil infiltrability in an agroforestry parkland in semiarid Burkina Faso, Water Resour. Res., 50, 3342-3354, 2014.

Belsky, A. J.: Influences of Trees on Savanna Productivity: Tests of Shade, Nutrients, and Tree-Grass Competition, Ecology, 75, 922-932, 1994.

Bhark, E. W. and Small, E. E.: Association between plant canopies and the spatial patterns of infiltration in shrubland and grassland of the Chihuahuan Desert, New Mexico, Ecosystems, 6, 185196, 2003.

Braud, I., Bariac, T., Gaudet, J. P., and Vauclin, M.: SiSPAT-Isotope, a coupled heat, water and stable isotope ( $\mathrm{HDO}$ and $\left.\left(\mathrm{H}_{2} \mathrm{O}\right)-\mathrm{O}-18\right)$ transport model for bare soil. Part I. Model description and first verifications, J. Hydrol., 309, 277-300, 2005.

Breman, H. and Kessler, J.-J.: Woody Plants in Agro-Ecosystems of Semi-Arid Regions Advanced Series in Agricultural Sciences, Springer Berlin, Heidelberg, 1999.

Caldwell, M. M.: Plant architecture and resource competition, edited by: Schulze, E.-D. and Zwoelfer, H., Ecological Studies, 164-179, 1987.

Caldwell, M. M., Dawson, T. E., and Richards, J. H.: Hydraulic lift: Consequences of water efflux from the roots of plants, Oecologia, 113, 151-161, 1998.

Cernusak, L. A., Barbour, M. M., Arndt, S. K., Cheesman, A. W., English, N. B., Feild, T. S., Helliker, B. R., Holloway, Phillips, M. M., Holtum, J., Kahmen, A., McInerney, F., Munksgaard, N. C., Simonin, K., Song, X., Stuart-Williams, H., West, J. B., and Farquhar, G. D.: Stable isotopes in leaf water of terrestrial plants, Plant Cell Environ., 39, 1087-1102, 2016.

Costa e Silva, F., Correia, A., Piayda, A., Dubbert, M., Rebmann, C., Cuntz, M., Werner, C., David, J., and Pereira, J. S.: Effects of extremely dry winter on net ecosystem carbon exchange and tree phenology at a cork oak woodland, Agr. Forest Meteorol., 204, 48-57, 2015.

Craig, H. and Gordon, L. I.: Deuterium and oxygen-18 variations in the ocean and the marine atmosphere. Paper presented at the Stable Isotopes in Oceanographic Studies and Paleotemperatures, Spoleto, Italy, 1965.

David, T. S., Gash, J. H., Valente, F., Pereira, J. S., Ferreira, M. I., and David, J.: Rainfall interception by an isolated evergreen oak tree in a Mediterranean savannah, GHydrological Processes, 20, 2713-2736, 2006.

Dawson, T. E.: Hydraulic lift and water-use by plants - implications for water-balance, performance and plant-plant interactions, Oecologia, 95, 565-574, 1993.

Devitt, D. A. and Smith, S. D.: Root channel macropores enhance downward movement of water in a Mojave Desert ecosystem, J. Arid Environ., 50, 99-108, 2002.

D'Odorico, P. and Porporato, A.: Soil moisture dynamics in water-limited ecosystems, in: Dryland Ecohydrology, edited by: D'Odorico, P. and Porporato, A., Springer Netherlands, 2006.

Duan, Q., Sorooshian, S., and Gupta, V.: Effective and efficient global optimization for conceptual rainfall-funoff models, Water Resour. Res., 28, 1015-1031, 1992.

Dubbert, M., Cuntz, M., Piayda, A., Maguas, C., and Werner, C.: Partitioning evapotranspiration - Testing the Craing and Gordon model with field measurements of oxygen isotope ratios of evaporative fluxes, J. Hydrol., 142-153, 2013.

Dubbert, M., Cuntz, M., Piayda, A., and Werner, C.: Oxygen isotope signatures of transpired water vapor - the role of isotopic nonsteady-state transpiration under natural conditions, New Phytol., 203, 1242-1252, 2014a.

Dubbert, M., Mosena, A., Piayda, A., Cuntz, M., Correia, A. C., Perreira, J. S., and Werner, C.: Influence of tree cover on herbaceous layer development and carbon and water fluxes in a Portuguese cork oak woodland, Acta Oecol., 59, 35-45, 2014b.

Dubbert, M., Piayda, A., Cuntz, M., Correia, A. C., Costa e Silva, F., Pereira, J. S., and Werner, C.: Stable oxygen isotope and flux partitioning demonstrates understory of an oak savanna contributes up to half of ecosystem carbon and water exchange, Frontiers in Plant Science, 5, 530, doi:10.3389/fpls.2014.00530, 2014c.

Dubbert, M., Kübert, A., and Werner, C.: Impact of Leaf Traits on Temporal Dynamics of Transpired Oxygen Isotope Signatures and Its Impact on Atmospheric Vapor, Frontiers in Plant Science, 8, 5, doi:10.3389/fpls.2017.00005, 2017.

Duckstein, L.: Multiobjective optimization in structural design: the model choice problem, in: New Directions in Optimum Structural Design, edited by: Atrek, E., Wiley, Chichester, 1981.

Ehleringer, J. R. and Dawson, T. E.: Water uptake by plants: perspectives from stable isotope composition, Plant Cell Environ., 15, 1073-1082, 1992.

Eldridge, D. J. and Freudenberger, D.: Ecosystem wicks: Woodland trees enhance water infiltration in a fragmented agricultural landscape in eastern Australia, Australian Ecology, 30, 336-347, 2005.

Eldridge, D. J., Bowker, M. A., Maestre, F. T., Alonso, P., Mau, R. L., Papadopoulos, J., and Escudero, A.: Interactive Effects of Three Ecosystem Engineers on Infiltration in a Semi-Arid Mediterranean Grassland, Ecosystems, 13, 499-510, 2010. 
Gaj, M., Beyer, M., Koeniger, P., Wanke, H., Hamutoko, J., and Himmelsbach, T.: In situ unsaturated zone water stable isotope $\left({ }^{2} \mathrm{H}\right.$ and $\left.{ }^{18} \mathrm{O}\right)$ measurements in semi-arid environments: a soil water balance, Hydrol. Earth Syst. Sci., 20, 715-731, doi:10.5194/hess-20-715-2016, 2016.

Garvelmann, J., Külls, C., and Weiler, M.: A porewater-based stable isotope approach for the investigation of subsurface hydrological processes, Hydrol. Earth Syst. Sci., 16, 631-640, doi:10.5194/hess-16-631-2012, 2012.

Goldshleger, N., Ben-Dor, E., Benyamini, Y., Blumberg, D., and Agassi, M.: Spectral properties and hydraulic conductance of soil crusts formed by raindrop impact, Int. J. Remote Sens., 23, 39093920, 2002.

Greig-Smith, P.: Pattern in Vegetation, J. Ecol., 67, 755-779, 1979.

Haverd, V. and Cuntz, M.: Soil-Litter-Iso: A one-dimensional model for coupled transport of heat, water and stable isotopes in soil with a litter layer and root extraction, J. Hydrol., 388, 438455, 2010.

Hipondoka, M., Aranibar, J., Chiara, C., Lihavha, M., and Macko, S.: Vertical distribution of grass and tree roots in arid ecosystems of Southern Africa: niche differentiation or competition?, J. Arid Environ., 54, 319-325, 2003.

Holdo, R. M. and Planque, R.: Revisiting the Two-Layer Hypothesis: Coexistence of Alternative Functional Rooting Strategies in Savannas, Plos One, 8, e69625, doi:10.1371/journal.pone.0069625, 2013.

IPCC: Climate Change 2013: The Physical Science Basis. Contribution of Working Group I to the Fifth Assessment Report of the Intergovernmental Panel on Climate Change, edited by: Stocker, T. F., Qin, D., Plattner, G.-K., Tignor, M., Allen, S. K., Boschung, J., Nauels, A., Xia, Y., Bex, V., and Midgley, P. M., Cambridge University Press, Cambridge, United Kingdom and New York, NY, USA, 1535 pp., 2013.

Joffre, R. and Rambal, S.: How tree cover influences the waterbalance of mediterranean rangelands, Ecology, 74, 570-582, 1993.

Kulmatiski, A. and Beard, K. H.: Root niche partitioning among grasses, saplings, and trees measured using a tracer technique, Oecologia, 171, 25-37, 2013.

Kulmatiski, A., Beard, K. H., Verqej, R. J. T., and February, E. C.: A depth-controlled tracer technique measures vertical, horizontal and temporal patterns of water use by trees and grasses in a subtropical savanna, New Phytol., 188, 199-209, 2010.

Kurz-Besson, C., Otieno, D., do Vale, R. L., Siegwolf, R., Schmidt, M., Herd, A., Nogueira, C., David, T. S.,David, J. S., Tenhunen, J., Pereira, J. S., and Chaves, M.: Hydraulic lift in cork oak trees in a savannah-type Mediterranean ecosystem and its contribution to the local water balance, Plant Soil, 282, 361-378, 2006.

Maestre, F. T., Huesca, M., Zaady, E., Bautista, S., and Cortina, J.: Infiltration, penetration resistance and microphytic crust composition in contrasted microsites within a Mediterranean semi-arid steppe, Soil Biol. Biochem., 34, 895-899, 2002.

Majoube, M.: Fractionation in O-18 Between Ice and Water Vapor, J. Chim. Phys. PCB, 68, 1424-1436, 1971.

Mathieu, R. and Bariac, T.: A numerical model for the simulation of stable isotope profiles in drying soils, J. Geophys. Res., 101, 12685-12696, 1996.

Merlivat, L.: Molecular Diffusivities of $\left(\mathrm{H}_{2} \mathrm{O}\right)-\mathrm{O}-16 \mathrm{HD}^{16} \mathrm{O}$, and $\left(\mathrm{H}_{2} \mathrm{O}\right)-\mathrm{O}-18$ in Gases, J. Chem. Phys., 69, 2864-2871, 1978.
Moreira, M. Z., Sternberg, L. D. L., Martinelli, L. A., Victoria, R. L., Barbosa, E. M., Bonates, L. C. M., and Nepstad, D. C.: Contribution of transpiration to forest ambient vapour based on isotopic measurements, Glob. Change Biol., 3, 439-450, 1997.

Moreno, G.: Response of understorey forage to multiple tree effects in Iberian dehesas, Agr. Ecosyst. Environ., 123, 239-244, 2008.

Nippert, J. B., Holdo, R. M. and Sayer, E.: Challenging the maximum rooting depth paradigm in grasslands and savannas, Funct. Ecol., 29, 739-745, 2015.

Orlowski, N., Frede, H.-G., Brüggemann, N., and Breuer, L.: Validation and application of a cryogenic vacuum extraction system for soil and plant water extraction for isotope analysis, Journal of Sensors and Sensor Systems, 2, 179-193, 2013.

Pape, L., Ammann, C., Nyfeler-Brunner, A., Spirig, C., Hens, K., and Meixner, F. X.: An automated dynamic chamber system for surface exchange measurement of non-reactive and reactive trace gases of grassland ecosystems, Biogeosciences, 6, 405429, doi:10.5194/bg-6-405-2009, 2009.

Philips, D. L., Newsome, S. D., and Gregg, J. W.: Combining sources in stable isotope mixing models: alternative methods, Oecologia, 144, 520-527, 2005.

Piayda, A., Dubbert, M., Rebmann, C., Kolle, O., Costa e Silva, F., Correia, A., Pereira, J. S., Werner, C., and Cuntz, M.: Drought impact on carbon and water cycling in a Mediterranean Quercus suber L. woodland during the extreme drought event in 2012, Biogeosciences, 11, 7159-7178, doi:10.5194/bg-11-7159-2014, 2014.

Piayda, A., Dubbert, M., Werner, C., Correia, A. V., Pereira, J. S., and Cuntz, M.: Influence of woody tissue and leaf clumping on vertically resolved leaf area index and angular gap probability estimates, Forest Ecol. Manage., 340, 103-113, 2015.

Porporato, A., Daly, E., and Rodriguez-Iturbe, I.: Soil Water Balance and Ecosystem Response to Climate Change, Am. Nat., 164, 625-632, 2004.

Pueyo, Y., Moret-Fernandez, D., Saiz, H., Bueno, C. G., and Alados, C. L.: Relationships Between Plant Spatial Patterns, Water Infiltration Capacity, and Plant Community Composition in Semiarid Mediterranean Ecosystems Along Stress Gradients, Ecosystems, 16, 452-466, 2012.

Rodriguez-Iturbe, I.: Ecohydrology: A hydrologic perspective of climate-soil-vegetation dynamics, Water Resour. Res., 36, 3-9, 2000.

Rothfuss, Y., Merz, S., Vanderborght, J., Hermes, N., Weuthen, A., Pohlmeier, A., Vereecken, H., and Brüggemann, N.: Longterm and high-frequency non-destructive monitoring of water stable isotope profiles in an evaporating soil column, Hydrol. Earth Syst. Sci., 19, 4067-4080, doi:10.5194/hess-19-40672015, 2015.

Scholes, R. J. and Archer, S. R.: Tree-grass interactions in savannas, Annual Reviews of Ecology and Systematics, 28, 517-544, 1997.

Schwinning, S. and Ehleringer, J. R.: Water use trade-offs and optimal adaptations to pulse-driven arid ecosystems, J. Ecol., 89, 464-480, 2001.

Tromble, J. M.: Water interception by 2 arid land shrubs, J. Arid Environ., 15, 65-70, 1988.

Volkmann, T. H. M., Haberer, K., Gessler, A., and Weiler, M.: Highresolution isotope measurements resolve rapid ecohydrological dynamics at the soil-plant interface, New Phytol., 210, 839-849, 2016a. 
Volkmann, T. H. M., Kühnhammer, K., Herbstritt, B., Gessler, A., and Weiler, M.: A method for in situ monitoring of the isotope composition of tree xylem water using laser spectroscopy, Plant Cell Environ., 39, 2055-2063, 2016 b.

von Caemmerer, S. and Farquhar, G. D.: Some relationships between the biochemistry of photosynthesis and the gas-exchange of leaves, Planta, 153, 376-387, 1981.

Walter, H., Burnett, J. H., and Mueller-Dombois, D.: Ecology of tropical and subtropical vegetation, Oliver and Boyd, Edinburgh, 1971.

Wang, L., D’Odorico, P., Evans, J. P., Eldridge, D. J., McCabe, M. F., Caylor, K. K., and King, E. G.: Dryland ecohydrology and climate change: critical issues and technical advances, Hydrol. Earth Syst. Sci., 16, 2585-2603, doi:10.5194/hess-16-25852012, 2012.
Werner, C. and Dubbert, M.: Resolving rapid dynamics of soilplant-atmosphere interactions, New Phytol., 210, 767-769, 2016.

Yakir, D. and Sternberg, L. D. L.: The use of stable isotopes to study ecosystem gas exchange, Oecologia, 123, 297-311, 2000.

Yepez, E. A., Williams, D. G., Scott, R. L., and Lin, G. H.: Partitioning overstory and understory evapotranspiration in a semiarid savanna woodland from the isotopic composition of water vapor, Agr. Forest Meteorol., 119, 53-68, 2003. 